\title{
Exogenous 5-Aminolevulenic Acid Promotes Antioxidative Defence System, Photosynthesis and Growth in Soybean against Cold Stress
}

\author{
Elahe MANAFI ${ }^{1}$, Seyed Ali Mohammad MODARRES SANAVY'*, \\ Majid AGHAALIKHANI ${ }^{1}$, Aria DOLATABADIAN ${ }^{2}$ \\ ${ }^{1}$ Tarbiat Modares University, Faculty of Agriculture, Agronomy Department, Tehran, Iran; modaresa@modares.acir ('corresponding author) \\ ${ }^{2}$ University of Western Australia, Faculty of Science, School of Plant Biology, Crawley 6000, Perth, WA, Australia
}

\begin{abstract}
In the present study, the possibility of enhancing cold stress tolerance of young soybean plants (Glycine max [L.] Merr) by exogenous application of 5-aminolevulinic acid (ALA) was investigated. ALA was applied at various concentrations $(0,0.3,0.6$ and $0.9 \mathrm{mM})$ by seed priming and foliar application method. After ALA treatment, the plants were subjected to cold stress at $10 \pm 0.5^{\circ} \mathrm{C}$ for $72 \mathrm{~h}$. Cold stress significantly decreased plant growth, relative water content, chlorophyll, photosynthesis and stomatal conductivity, while it increased electrolyte leakage and proline accumulation. ALA at low concentrations $(0.3 \mathrm{mM})$ protected plants against cold stress, enhancing plant height, shoot fresh and dry weight, chlorophyll content, photosynthesis, stomatal conductivity as well as relative water content. Increase of electrolyte leakage was also prevented by $0.6 \mathrm{mM}$ ALA. ALA also enhanced superoxide dismutase and catalase activities at $0.6 \mathrm{mM}$ concentration especially under cold stress conditions. Proline increased with increasing in ALA concentration under both temperature conditions. In most cases, application of ALA by spraying method was better than seed priming method. Results showed that ALA, which is considered as an endogenous plant growth regulator, can be used effectively to protect soybean plants from the damaging effects of cold stress, by enhancing the activity of antioxidative enzymes, protecting cell membrane against reactive oxygen species and finally by promoting chlorophyll synthesis, leading to more intense photosynthesis and more carbon fixation, without any adverse effect on the plant growth.
\end{abstract}

Keywords: 5-aminolevulinic acid, cold stress, foliar application, priming, soybean

\section{Introduction}

About two thirds of the world's landmass is annually subjected to temperatures below the freezing point and about half of it suffers from temperatures below $-20{ }^{\circ} \mathrm{C}$ (Larcher, 2001). Low temperature may impose stress on a plant in a two-fold manner: by the effects of low temperature alone, and by dehydration of the cells and tissues when cellular water freezes (Beck et al., 2004). The plant response to low temperature stress can be divided into three distinct phases. The first is cold acclimation, which occurs at low, but above zero temperatures. The second stage, during which the full degree of tolerance is achieved, requires exposure to a period of sub-zero temperatures. The final phase is plant recovery after winter (Li et al., 2008). Low temperatures above the freezing point are deleterious to many crops of the tropics and subtropics which cannot acclimatize to cold. This kind of damage has been termed 'chilling' (Sakai and Larcher, 1987). Low temperature effects include damaged membranes (Xing and Rajashekar, 2001), reduced cellular respiration (Lee and Lur, 1997), increased abscisic acid levels (Nayyar et al., 2005), cryoprotectants and increased reactive oxygen species (Lee and Lur, 1997) which arises from imbalances of electron transport rate and the metabolic consumer activity of the reductive power (Beck et al., 2007). Cold acclimation is a process by which plants acquire freezing tolerance upon prior exposure to low nonfreezing temperatures. Over wintering temperate plant species acclimatise during autumn, during which their metabolism is redirected towards synthesis of cryoprotectant molecules such as soluble sugars (saccharose, raffinose, stachyose, trehalose), sugar alcohols (sorbitol, ribitol, inositol) and low-molecular weight nitrogenous compounds (proline, glycine betaine) (Janská et al., 2010). Most temperate plants can cold-acclimate and acquire tolerance to extracellular ice formation in their vegetative tissues, while many important crops, such as rice, maize, soybean and cotton are chilling sensitive and incapable of cold acclimation. Given the fact that soybean plants are from subtropical regions, it is not surprising that they are particularly sensitive to cold. In addition, its cultivation is successful in climates with hot summers and temperatures below $20^{\circ} \mathrm{C}$ and over $40^{\circ} \mathrm{C}$ retard its growth significantly (Balestrasse et al., 2010). Following the expansion of soybean plants growing areas towards colder climates, acclimation to cold conditions has become a 


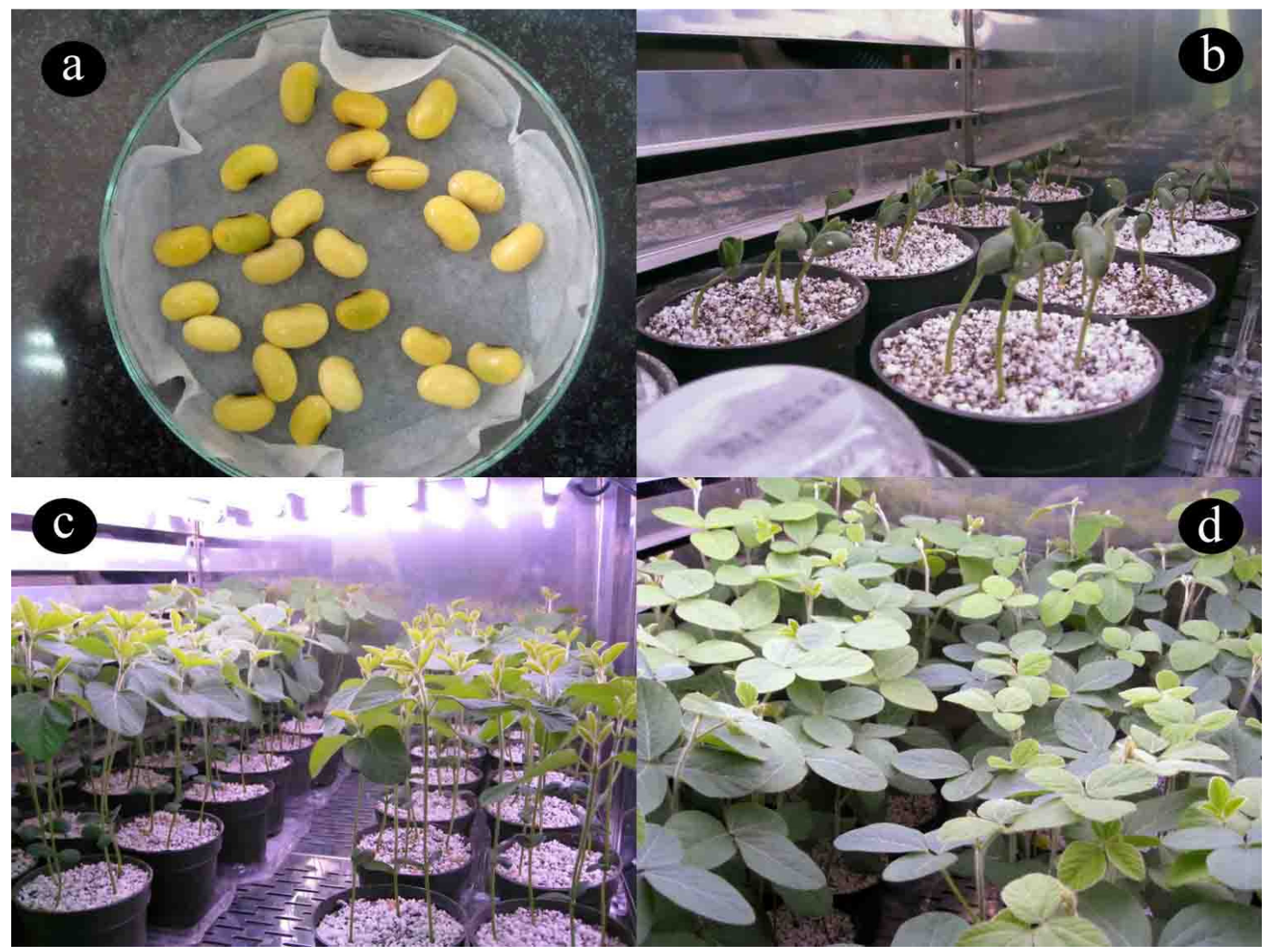

Fig. 1. Soybean growth under controlled conditions: a) Seed priming with ALA; b) Three day soybean seedlings; c) Cold stress induction; d) forty day soybean plants

major research target. Moreover, the combination of high light intensities and low temperatures, such as those experienced on cold but sunny mornings in spring, can cause irreversible damage to young soybean plants seedlings (Balestrasse et al., 2010). The sensitivity of soybean to night temperatures below $15^{\circ} \mathrm{C}$ is reflected in the changes that occur in metabolism, growth, development and yield (Musser et al., 1983, 1984; Van Heerden et al., 2003). A single night of dark cold, with minimum temperatures of 8 ${ }^{\circ} \mathrm{C}$, is sufficient to inhibit pod formation (Hume and Jackson, 1981). Therefore stress tolerance has become a major selection criterion in current soybean plants breeding programmers (Balestrasse et al., 2010).

5-Aminolevulinic acid (ALA) with a molecular weight of 131 is the first compound in the porphyrin synthesis pathway, the pathway that leads to heme in mammals and chlorophyll in plants. In higher plants, ALA is synthesized from glutamate in a reaction involving a glutamyl tRNA intermediate and requiring $\mathrm{ATP}$ and $\mathrm{NADPH}$ as cofactors; its formation is the rate limiting step in chlorophyll biosynthesis (Castelfranco et al., 1974; Beale, 1990). The keto-amino acid ALA is an essential precursor in the biosynthesis of porphyrins such as chlorophyll, heme, vitamin $\mathrm{B}_{12}$ and other tetrapyrrole compounds (Stobart and Ameen-Bukhari, 1984). ALA is found in all plants and its concentration is regulated at low concentrations (Weinstein and Beale, 1985; Hotta et al., 1997b). Recently, it was found that ALA at low concentration has a promotive effect on growth and yield of several field crops (Hotta et al., 1997a, b; Watanabe et al., 2000). It has been reported that ALA at low concentrations can also increase cold resistance in rice seedlings (Hotta et al., 1998). Similarly, Hotta et al. (1998) and Zhang et al. (2006) showed that ALA increased cold and salt tolerance in rice and potato. It is also known that ALA biosynthesis in plants is inhibited by low and high temperatures (Hodgins and Öquist, 1989; Tewari and Tripathy, 1998). From previous studies, low concentrations of ALA could enhance the antioxidant level in spinach and pakchoi (Nishihara et al., 2003; Memon et al., 2009) and enhance plant's tolerance to cold stress (Hotta et al., 1998; Wang et al., 2004). Exogenous application of ALA is a novel strategy and has been considered as an effective means of minimizing the coldinduced adverse effects. However, there are few reports about assessing the effects of exogenous application of ALA on soybean under cold stress conditions. Therefore, in the current study, the effects of exogenous ALA at different concentration and two methods of application, seed priming and foliar application, regarding the cold stress induced growth, physiological and biochemical responses in soybean were investigated.

\section{Materials and Methods}

Seeds of soybean (Glycine max L. c.v '032') were surface sterilized in a hydrogen peroxide/ethanol solution for 2 min $\left(10 \mathrm{ml}\right.$ of $30 \% \mathrm{H}_{2} \mathrm{O}_{2}$ and $75 \mathrm{ml}$ of $96 \%$ ethanol filled up to $100 \mathrm{ml}$ with sterile distilled water) and rinsed several times with sterile distilled water. Half of the seeds were 
488

Table 1. Analysis of variance on different soybean traits affected by temperature, ALA concentration and method of application

\begin{tabular}{|c|c|c|c|c|c|c|c|c|c|c|c|c|c|c|}
\hline 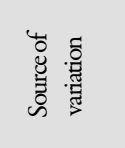 & 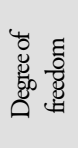 & 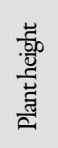 & 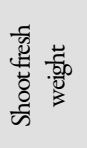 & 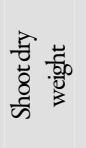 & 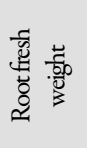 & 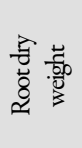 & 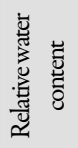 & 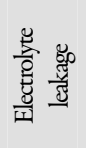 & 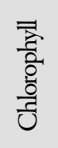 & 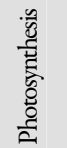 & 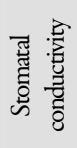 & 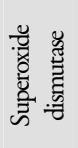 & 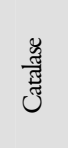 & $\begin{array}{l}\text { 咅 } \\
\text { ص }\end{array}$ \\
\hline $\mathrm{R}$ & 2 & ns & $\mathrm{ns}$ & ns & $\mathrm{ns}$ & ns & $\mathrm{ns}$ & ns & ns & $\mathrm{ns}$ & ns & $\mathrm{ns}$ & ns & ns \\
\hline $\mathrm{T}$ & 1 & $* *$ & $* *$ & $* *$ & ns & $* *$ & $* *$ & $* *$ & $* *$ & $* *$ & $* *$ & $* *$ & $* *$ & $* *$ \\
\hline M & 1 & ns & ns & ns & ns & ns & ns & ns & ns & ns & $* *$ & ns & ** & $* *$ \\
\hline $\mathrm{C}$ & 3 & $* *$ & $* *$ & ** & ns & $* *$ & $* *$ & ** & ** & $* *$ & ** & ** & ** & $* *$ \\
\hline $\mathrm{M} \times \mathrm{C}$ & 3 & ns & ns & ns & $\mathrm{ns}$ & ns & ns & * & $* *$ & ns & * & $\mathrm{ns}$ & $* *$ & $\mathrm{~ns}$ \\
\hline $\mathrm{T} \times \mathrm{M}$ & 1 & ns & ns & ns & ns & ns & ns & * & $* *$ & ns & * & ns & ** & $* *$ \\
\hline $\mathrm{T} \times \mathrm{C}$ & 3 & $* *$ & $* *$ & ns & $\mathrm{ns}$ & * & $* *$ & $* *$ & $* *$ & ns & $* *$ & * & $*$ & $* *$ \\
\hline $\mathrm{T} \times \mathrm{M} \times \mathrm{C}$ & 3 & ns & ns & ns & ns & ns & ns & * & $* *$ & ns & $* *$ & ns & $* *$ & $* *$ \\
\hline $\mathrm{CV}$ & & 2.43 & 9.44 & 25.29 & 18.48 & 26.26 & 10.97 & 10.16 & 5.51 & 17.29 & 12.83 & 20.06 & 11.15 & 2.33 \\
\hline
\end{tabular}

R: replication; T: Temperature; M: Method of application; C: Concentration

Table 2. Interaction between temperature and ALA concentration

\begin{tabular}{|c|c|c|c|c|c|c|}
\hline Temperature & 5-aminolevulinic acid & $\begin{array}{l}\text { Plant height } \\
\text { (cm) }\end{array}$ & $\begin{array}{l}\text { Shoot fresh } \\
\text { weight (g) }\end{array}$ & $\begin{array}{c}\text { Root dry } \\
\text { Weight (g) }\end{array}$ & $\begin{array}{c}\text { Relative water content } \\
(\%)\end{array}$ & $\begin{array}{c}\text { Superoxide dismutase } \\
\left(\Delta \text { Abs mgprotein }{ }^{-1} \min ^{-1}\right)\end{array}$ \\
\hline \multirow{3}{*}{$\begin{array}{l}\text { Cold stress } \\
\left(10^{\circ} \mathrm{C}\right)\end{array}$} & $0 \mathrm{mM}$ & $48.16 f$ & $2.38 \mathrm{~d}$ & $0.19 \mathrm{e}$ & $1.17 \mathrm{fg}$ & $3.10 \mathrm{c}$ \\
\hline & $0.3 \mathrm{mM}$ & $61.33 a$ & $5.69 \mathrm{a}$ & $0.24 \mathrm{e}$ & $2.03 e^{\circ}$ & $4.08 \mathrm{~b}$ \\
\hline & $0.6 \mathrm{mM}$ & $58.16 \mathrm{~b}$ & $4.62 \mathrm{~b}$ & 0.30de & $1.49 \mathrm{f}$ & $5.55 \mathrm{a}$ \\
\hline \multirow{5}{*}{$\begin{array}{l}\text { Nonestress } \\
\left(25^{\circ} \mathrm{C}\right)\end{array}$} & $0.9 \mathrm{mM}$ & $54.16 \mathrm{~d}$ & $3.66 c$ & $0.44 b c$ & $0.74 \mathrm{~g}$ & $5.29 \mathrm{a}$ \\
\hline & $0 \mathrm{mM}$ & $52.33 e$ & $4.38 \mathrm{~b}$ & $0.25 \mathrm{e}$ & $5.54 \mathrm{c}$ & $2.17 \mathrm{~d}$ \\
\hline & $0.3 \mathrm{mM}$ & $60.66 a$ & $5.40 \mathrm{a}$ & $0.38 \mathrm{~cd}$ & $6.12 b$ & $2.57 \mathrm{~cd}$ \\
\hline & $0.6 \mathrm{mM}$ & $60.00 \mathrm{a}$ & $4.77 \mathrm{~b}$ & $0.53 b$ & $6.61 \mathrm{a}$ & $2.95 \mathrm{~cd}$ \\
\hline & $0.9 \mathrm{mM}$ & $56.50 c$ & $3.59 \mathrm{c}$ & $0.77 \mathrm{a}$ & $4.67 \mathrm{~d}$ & $2.92 \mathrm{~cd}$ \\
\hline \multicolumn{2}{|c|}{$\operatorname{LSD}(5 \%)$} & 1.62 & 0.48 & 0.12 & 0.45 & 0.84 \\
\hline
\end{tabular}

immersed in different concentration of 5-aminolevulinic acid comprised of $0,0.3,0.6$ and $0.9 \mathrm{mM}$, another half of seeds were imbibed in distilled water. After $3 \mathrm{~h}$ incubation at $25^{\circ} \mathrm{C}$, four seeds of each group were planted out in 10 $\mathrm{cm}$ diameter plastic pots containing autoclaved peat and perlite (3:1 ratio) at depth of $1-3 \mathrm{~cm}$ (totally 48 pots). The pots were placed in a growth cabinet $(\mathrm{L} / \mathrm{D}=16 / 8 \mathrm{~h}$, $\mathrm{T}=28 / 25^{\circ} \mathrm{C}$ and a light intensity of $\left.175 \mu \mathrm{mol} \mathrm{m} \mathrm{s}^{-1}\right)$ and watered with full strength of Broughton and Dilworth solution (B\&D) (Broughton and Dilworth, 1971) containing $8 \mathrm{mM} \mathrm{KNO}_{3}$ (Fig. 1). Throughout the growth period, each pot received $50 \mathrm{ml}$ of $\mathrm{B} \& \mathrm{D}$ nutrient solution. After two weeks growth, plants grown from untreated seeds were sprayed with $0,0.3,0.6$ and $0.9 \mathrm{mM} 5$ aminolevulinic acid. Three days after foliar application, half of pots (12 pots from each group) were subjected to cold stress at $10 \pm 0.5^{\circ} \mathrm{C}$ for $72 \mathrm{~h}$, under the same light regime as indicated above. For comparison purposes, plants not exposed to cold stress and grown in the growth chamber at $25^{\circ} \mathrm{C}$ were used as controls. Physiological and biochemical traits were determined immediately at the end of cold stress. At this time, a Li-6400 instrument (Li-Cor, Lincoln, USA) was used for measurement of photosynthesis and stomatal conductivity. Plants were removed from pots 40 days after initiation of the experiment. The roots were gently washed with water to remove all peat and perlite. Afterwards the shoot and root were detached and weighed, then dried at $70^{\circ} \mathrm{C}$ for $24 \mathrm{~h}$ to calculate dry weight. The experiment was carried out with three replicates and all treatments were arranged in a randomized complete blocks design arranged in factorial $3(2 \times 2 \times 4)$.

\section{Relative water content}

Relative water content (RWC), expressed as a percentage was determined in soybean leaves according to the formula:

RWC $(\%)=[(\text { FW }- \text { DW }) /(\text { SW }- \text { DW })]^{*} 100$,

where FW, DW and SW mean fresh weight, dry weight and saturated weight, respectively. FW was measured just after collection of the leaves at the end of the cold stress and DW was measured after drying the leaves at $70^{\circ} \mathrm{C}$ for $48 \mathrm{~h}$.

\section{Electrolyte leakage}

Electrolyte leakage was determined by the procedure described by Dionisio-Sese and Tobita (1998). Leaf discs $(100 \mathrm{mg})$ were thoroughly washed in distilled water thereafter the discs were heated in $10 \mathrm{ml}$ of double distilled water at $25^{\circ} \mathrm{C}$ for $2 \mathrm{~h}$. Then electrical conductivity was recorded by EC meter $\left(\mathrm{C}_{1}\right)$. Subsequently the same samples were autoclaved at $121{ }^{\circ} \mathrm{C}$ for $20 \mathrm{~min}$ and then their electrical conductivity was also recorded $\left(\mathrm{C}_{2}\right)$. The electrolyte leakage was calculated as:

Electrolyte leakage $=\left(\mathrm{C}_{1} / \mathrm{C}_{2}\right) \times 100$.

\section{Chlorophyll}

Chlorophyll was extracted in $80 \%$ acetone from the leaf samples according to the method of Arnon (1949). Extracts were filtrated and content of total chlorophyll was determined by spectrophotometry at 645 and $663 \mathrm{~nm}$, respectively. The content of chlorophyll was expressed as $\mathrm{mg} \mathrm{g}^{-1}$ fresh weight according to the formula:

Total chlorophyll $=$

$=[20.2(\mathrm{D} 645)+8.02(\mathrm{D} 663)] \times \mathrm{V} / 1000 \mathrm{~W}$. 


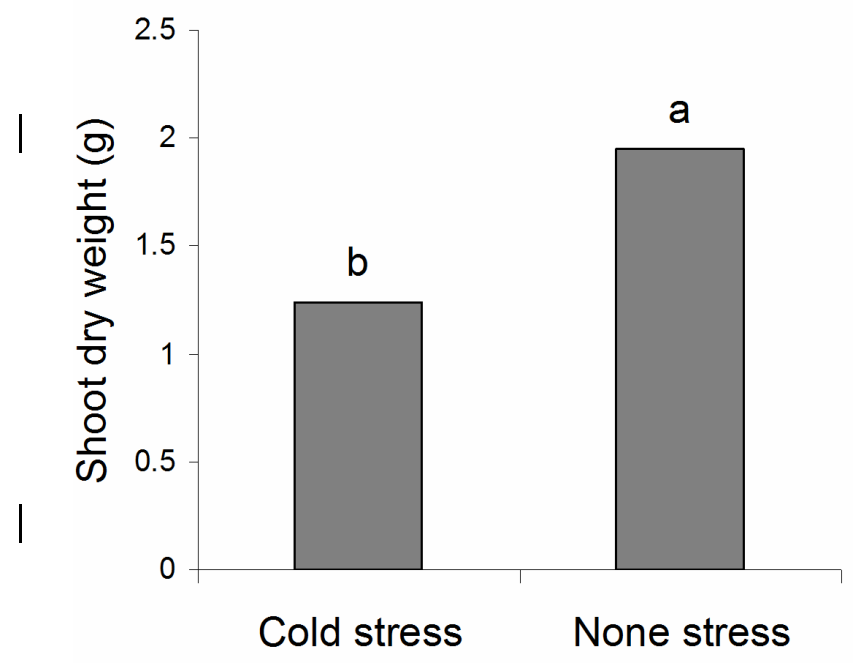

Fig. 2. Effect of cold stress on soybean shoot dry weight. Treatment means followed by the same letter within each common are not significantly different $(\mathrm{P}<0.05)$ according to LSD test

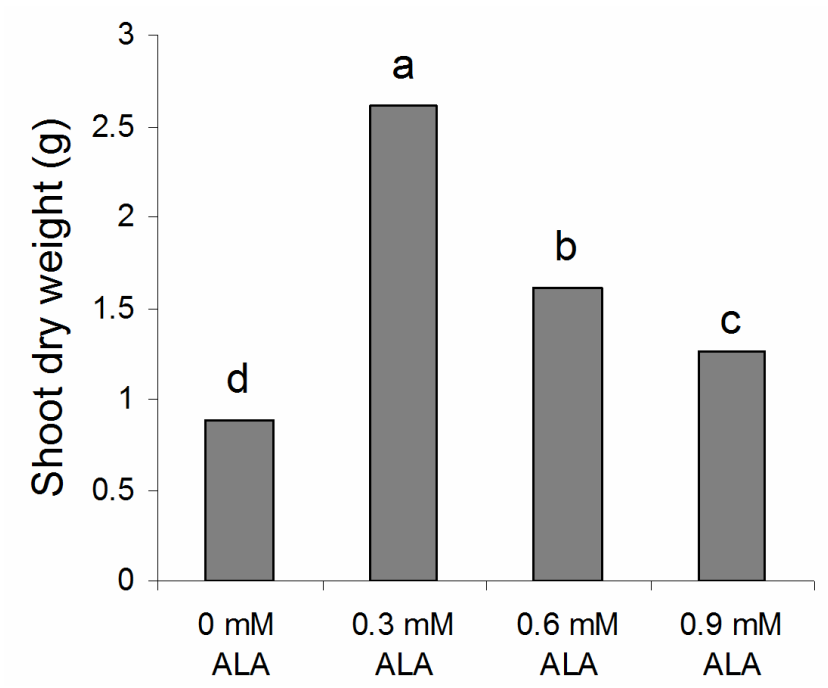

Fig. 3. Effect of ALA concentrations on soybean shoot dry weight. Treatment means followed by the same letter within each common are not significantly different $(\mathrm{P}<0.05)$ according to LSD test

\section{Superoxide dismutase (SOD)}

Superoxide dismutase activity was determined by measuring the ability of the enzyme extract to inhibit the photochemical reduction of nitroblue tetrazolium according to the method of Giannopolitis and Ries (1977). The reaction mixture contained $100 \mu \mathrm{l}, 1 \mu \mathrm{M}$ riboflavin, $100 \mu \mathrm{l} 12 \mathrm{mM}$ L-methionine, $100 \mu \mathrm{l} 0.1 \mathrm{mM}$ EDTA (pH 7.8), $100 \mu \mathrm{l} 50$ mm Na $\mathrm{CO}_{3}$ (pH 10.2), 100 $\mu l 75 \mu \mathrm{M}$ NBT in $2.3 \mathrm{ml} 25 \mathrm{mM}$ sodium phosphate buffer (pH 6.8) and $200 \mu \mathrm{l}$ crude enzyme extract, in a final volume of $3 \mathrm{ml}$. Glass test tubes that contained the reaction mixture were illuminated with a fluorescent lamp $(120 \mathrm{~W})$, while identical tubes that were not illuminated served as blanks. After illumination for $45 \mathrm{~min}$, absorbance was measured at $560 \mathrm{~nm}$. One unit of superoxide dismutase activity was defined as the amount of enzyme that caused $50 \%$ inhibition of photochemical reduction of nitroblue tetrazolium.

\section{Catalase}

Catalase activity was estimated by the method of Cakmak and Horst (2006). The reaction mixture contained $100 \mu \mathrm{l}$ crude extract, $500 \mu \mathrm{l} 10 \mathrm{mM} \mathrm{H}_{2} \mathrm{O}_{2}$ and $1.4 \mathrm{ml} 25 \mathrm{mM}$ potassium phosphate buffer. The decrease in absorbance was recorded at $240 \mathrm{~nm}$ for 1 min using a spectrophotometer (Cintra GBC, Dandenong, Victoria, Australia). Catalase activity of the extract was expressed as Abs $\mathrm{mg}^{-1}$ protein $\mathrm{min}^{-1}$.

\section{Proline}

Proline content of leaves and roots was determined according to method of Bates et al. (1973). Samples (0.2 g) were homogenized in a mortar and pestle with $3 \mathrm{ml}$ sulphosalicylic acid $(3 \% \mathrm{w} / \mathrm{v})$ and then centrifuged at $12,000 \mathrm{rpm}$ for $15 \mathrm{~min}$. Two $\mathrm{ml}$ of the supernatant were added to a test tube and then two ml glacial acetic acid and two $\mathrm{ml}$ freshly prepared acid ninhydrin solution were added. The test tubes were incubated in a water bath for one $\mathrm{h}$ at $100{ }^{\circ} \mathrm{C}$ and then allowed to cool to room temperature. Four $\mathrm{ml}$ of toluene was added to the tubes and mixed on a vortex mixer for $20 \mathrm{~s}$. The test tubes were allowed to stand for at least $10 \mathrm{~min}$, to allow separation of the toluene and aqueous phases. The toluene phase was carefully pipetted out into a glass test tube and its absorbance was measured at $520 \mathrm{~nm}$ in a spectrophotometer. The content of proline was calculated from a standard curve, and was expressed as $\mathrm{mg} \mathrm{g}^{-1}$ fresh weight.

\section{Statistical analysis}

For all variables, analysis of variance (ANOVA) was performed using the GLM procedure in SAS version 9.1. Main and interaction effects of experimental factors were determined. Where interactions between two factors were significant, it has been presented the results in the form of a combination of treatments and not separately or individually. The significance of differences among treatment means was compared by LSD at the $5 \%$ probability level.

\section{Results and Discussion}

\section{beight}

Effect of cold stress and 5-Aminolevulinic acid on plant

Analysis of variance showed that there was a significant effect of the cold stress and ALA treatments as well as the interaction of them on plant height. There was no significant effect of the ALA application method (Table 1). Plant height significantly decreased by cold stress treatment and increased by ALA application (Table 2). The highest plants were observed when 0.3 and $0.6 \mathrm{mM}$ ALA was applied either in stressed plants or unstressed plants (Table 2). On the other hand, the shortest plants were observed in the control treatment (no stress and no ALA application). It is notable that further increase in 
490

Table 3. Interaction between temperature, ALA concentration and method of application

\begin{tabular}{|c|c|c|c|c|c|c|c|}
\hline Temperature & $\begin{array}{l}\text { Method of } \\
\text { application }\end{array}$ & Concentration & $\begin{array}{l}\text { Electrolyte } \\
\text { leakage(\%) }\end{array}$ & $\begin{array}{l}\text { Chlorophyll } \\
\left(\mathrm{mgg}^{-1} \mathrm{FW}\right)\end{array}$ & $\begin{array}{l}\text { Stomatal conductivity } \\
\qquad\left(\mathrm{mol} \mathrm{m}^{-2} \mathrm{~s}^{-1}\right)\end{array}$ & $\begin{array}{c}\text { Catalase } \\
\left(\Delta \text { Abs mgprotein }{ }^{-1}\right. \\
\left.\min ^{-1}\right)\end{array}$ & $\begin{array}{c}\text { Proline } \\
\left(\mathrm{mgg}^{-1} \mathrm{FW}\right)\end{array}$ \\
\hline \multirow{8}{*}{$\begin{array}{l}\text { Cold stress } \\
\left(10^{\circ} \mathrm{C}\right)\end{array}$} & \multirow{4}{*}{ Seed priming } & $0 \mathrm{mM}$ & $85.27 \mathrm{a}$ & $1.42 j$ & $0.01 \mathrm{~g}$ & $1.37 \mathrm{def}$ & $9.02 \mathrm{~h}$ \\
\hline & & $0.3 \mathrm{mM}$ & $65.85 \mathrm{~b}$ & $2.72 \mathrm{a}$ & $0.06 \mathrm{ab}$ & $1.72 c$ & $18.28 \mathrm{e}$ \\
\hline & & $0.6 \mathrm{mM}$ & $23.67 \mathrm{e}$ & $1.94 \mathrm{gh}$ & $0.04 \mathrm{cde}$ & $2.44 b$ & $22.87 \mathrm{c}$ \\
\hline & & $0.9 \mathrm{mM}$ & $48.70 c$ & 1.75hi & $0.02 \mathrm{fg}$ & $1.42 \mathrm{de}$ & $29.06 \mathrm{a}$ \\
\hline & \multirow{4}{*}{$\begin{array}{c}\text { Foliar } \\
\text { application }\end{array}$} & $0 \mathrm{mM}$ & $88.83 \mathrm{a}$ & $1.77 \mathrm{hi}$ & $0.01 \mathrm{~g}$ & $1.28 \mathrm{efg}$ & $9.25 \mathrm{~h}$ \\
\hline & & $0.3 \mathrm{mM}$ & $65.74 b$ & $2.40 \mathrm{bcd}$ & $0.05 \mathrm{abc}$ & $1.64 \mathrm{~cd}$ & $17.13 \mathrm{f}$ \\
\hline & & $0.6 \mathrm{mM}$ & $15.82 \mathrm{f}$ & $2.05 \mathrm{fg}$ & $0.04 \mathrm{de}$ & $3.47 \mathrm{a}$ & $18.59 \mathrm{e}$ \\
\hline & & $0.9 \mathrm{mM}$ & $36.56 \mathrm{~d}$ & $2.23 \mathrm{cdef}$ & $0.02 \mathrm{f}$ & $1.47 \mathrm{cde}$ & $24.41 b$ \\
\hline \multirow{9}{*}{$\begin{array}{l}\text { None stress } \\
\left(25^{\circ} \mathrm{C}\right)\end{array}$} & \multirow{4}{*}{ Seed priming } & $0 \mathrm{mM}$ & $13.86 \mathrm{f}$ & $2.37 \mathrm{cde}$ & $0.04 \mathrm{e}$ & 1.13 fgh & $4.25 j$ \\
\hline & & $0.3 \mathrm{mM}$ & $12.07 \mathrm{f}$ & 2.61ab & $0.06 \mathrm{a}$ & $0.91 \mathrm{hi}$ & $6.73 \mathrm{i}$ \\
\hline & & $0.6 \mathrm{mM}$ & $12.04 \mathrm{f}$ & 2.21def & $0.05 \mathrm{ab}$ & $0.71 \mathrm{ij}$ & $18.30 \mathrm{e}$ \\
\hline & & $0.9 \mathrm{mM}$ & $13.06 \mathrm{f}$ & $2.17 \mathrm{ef}$ & $0.05 \mathrm{bcd}$ & $1.20 \mathrm{efg}$ & 21.31d \\
\hline & \multirow{4}{*}{$\begin{array}{c}\text { Foliar } \\
\text { application }\end{array}$} & $0 \mathrm{mM}$ & $15.30 f$ & $2.44 \mathrm{bc}$ & $0.04 \mathrm{e}$ & $0.62 \mathrm{j}$ & $3.90 \mathrm{j}$ \\
\hline & & $0.3 \mathrm{mM}$ & $11.66 f$ & 2.20def & $0.05 \mathrm{abc}$ & $1.27 \mathrm{efg}$ & $5.87 \mathrm{i}$ \\
\hline & & $0.6 \mathrm{mM}$ & $12.06 \mathrm{f}$ & $1.69 \mathrm{i}$ & $0.05 \mathrm{abcd}$ & $2.68 b$ & $6.11 \mathrm{i}$ \\
\hline & & $0.9 \mathrm{mM}$ & $14.66 f$ & $2.06 \mathrm{fg}$ & $0.03 \mathrm{f}$ & 1.01gh & $14.32 \mathrm{~g}$ \\
\hline & $\operatorname{LSD}(5 \%)$ & & 5.66 & 0.21 & 0.00 & 0.28 & 1.00 \\
\hline
\end{tabular}

ALA concentration $(0.9 \mathrm{mM})$ showed no increase in plant height (Table 2). Temperature within the chilling range can limit the soybean growth at all phenological stages. The present results support the claim of the former reports that low temperature had been identified as being powerful inhibitors for plant growth (Ercoli et al., 2004; Rodríguez et al., 2005; Xia et al., 2009). Earlier studies have shown that temperature alters the plant's auxin response by altering its biosynthesis (Gray et al., 1998), whereas cold temperature affects the polar and lateral transport of auxin (Wyatt et al., 2002; Nadella et al., 2006) a decrease in plant height is expected to bring modifications to the internode length or number. Although these studies demonstrate a link between auxin and temperature stress, the molecular and cellular mechanisms that regulate the auxin response under temperature stress, particularly for cold, remain elusive (Shibasaki et al., 2009). It has been found that low concentrations of ALA had a promotive effect on soybean plant height. It was reported that a low concentration of ALA had a promotion effect on cold resistance in rice (Hotta et al., 1998). Such type of ALA induced growth improvement has already been studied in date palm, potato, oilseed rape, pakchoi etc. (Youssef and Awad, 2008; Naeem et al., 2010).

\section{Effect of cold stress and 5-Aminolevulinic acid on plant weight}

As can be seen from Table 1, interaction of temperature $\times$ ALA concentration was significant on shoot fresh weight while shoot dry weight was only affected by individual effect of temperature and ALA concentration. Exposure to cold stress dramatically reduced the shoot fresh weight in untreated plants with ALA (Table 2). It is interesting to remark that there was no significant difference between the two temperature regimes when ALA was applied. Shoot fresh weight reached its maximum value on account of $0.3 \mathrm{mM}$ ALA and then reduced with increase in ALA concentration
(Table 2). Shoot dry weight was inhibited significantly under cold stress (Fig. 2). By contrast, it increased because of $0.3 \mathrm{mM}$ ALA application; however the rate of increase decreased consistently with increased ALA concentration (Fig. 3). Similar results were obtained in the case of root dry weight, whereas cold stress decreased root dry weight whiles ALA increased (Table 2). Root fresh weight was affected neither by cold stress nor by ALA application. These results indicate that ALA treatment not only counteracted cold stress damage but also stimulated the growth and dry matter accumulation through increased chlorophyll content and photosynthetic $\mathrm{CO}_{2}$ absorption. It also has been found that plants treated with $0.3 \mathrm{mM}$ ALA produced the highest shoot fresh weights, whereas a higher concentration of ALA decreased the growth. The increase in fresh or dry weight may be attributed to the rate of photosynthesis which in turn might influence the photosynthate production and translocation. Moreover, this increase may also be attributed to the promotive effects of ALA on phloem transport (Bindu Roy and Vivekanandan, 1998). The present findings are in agreement with Hotta et al. (1997a) and Watanabe et al. (2006) who demonstrated that low concentrations of ALA improve growth rates and photosynthesis in barley, potato, radish, garlic, kidney bean and grapevines.

\section{Effect of cold stress and 5-Aminolevulinic acid on relative} water content

Table 2 shows that RWC decreased under cold stress respect to controls $\left(25^{\circ} \mathrm{C}\right)$. Treatment with ALA protected against this effect. Treatment with $0.9 \mathrm{mM}$ ALA under cold stress conditions showed a major RWC loss respect to controls. Conversely, the highest RWC value was related to $0.6 \mathrm{mM}$ ALA treatment under none cold stress conditions (Table 2). Measurement of RWC showed that RWC decreased in leaves at the end of cold stress, which is likely to be due to decline in hydraulic conductivity of roots. This claim is in agreement with data of the literature, showing a decline in water uptake at low temperature (Wilkinson et al., 2001). In addition, Aroca et al. (2001) reported decrease in RWC under chilling stress in maize plant due to dehydration, in 


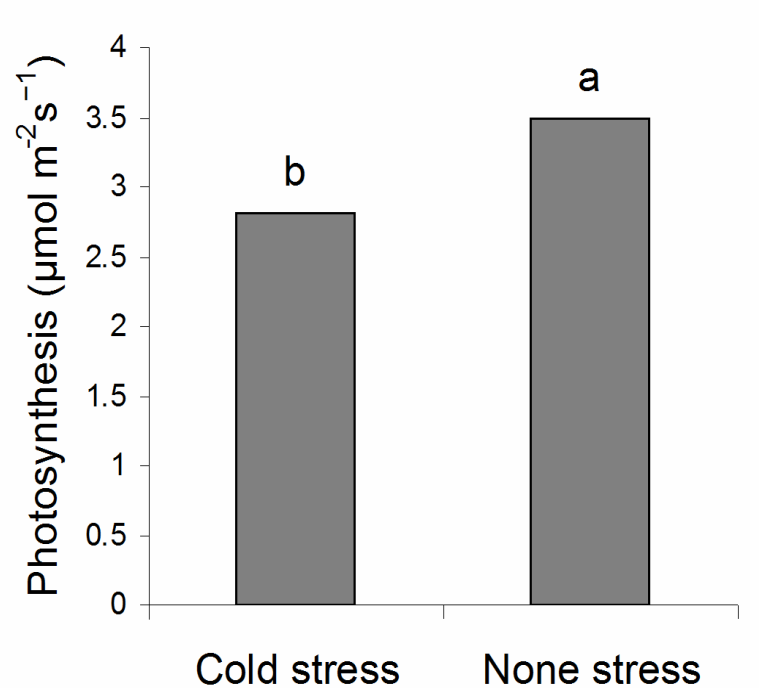

Fig. 4. Effect of cold stress on soybean photosynthesis. Treatment means followed by the same letter within each common are not significantly different $(\mathrm{P}<0.05)$ according to LSD test

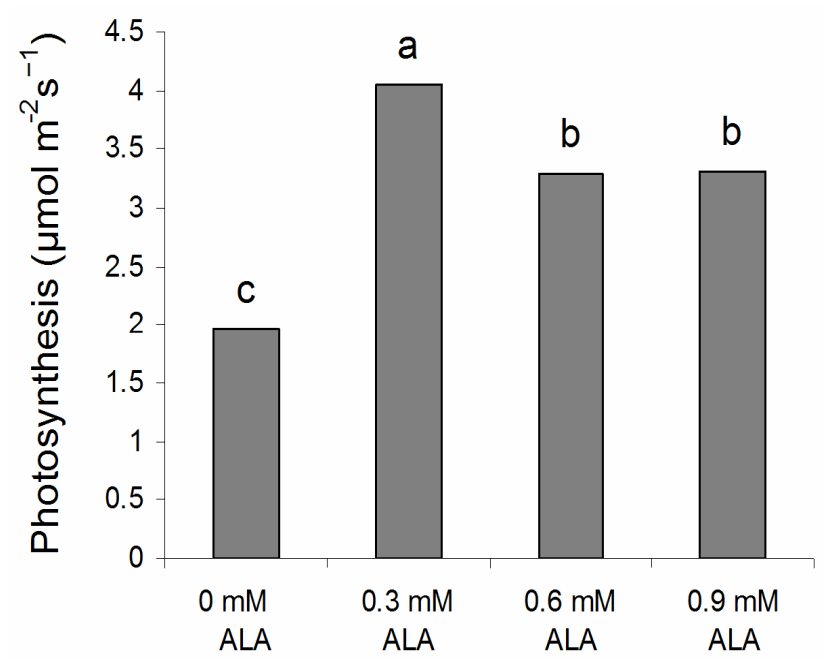

Fig. 5. Effect of different ALA concentrations on soybean photosynthesis. Treatment means followed by the same letter within each common are not significantly different $(\mathrm{P}<0.05)$ according to LSD test

agreement with the current results. The ALA treatment significantly increased RWC over the control and also overcome the adverse effect caused by cold. This increase in RWC might be due to increase in plant growth attributes.

\section{Effect
leakage
Inths}

Effect of cold stress and 5-Aminolevulinic acid on electrolyte

In this study, electrolyte leakage was affected by different temperature regimes and ALA concentrations, but not by method of ALA treatment (Table 1). The electrolyte leakage of soybean plants presented in this work decreased with increasing ALA concentration up to $0.6 \mathrm{mM}$ and then increased slightly due to $0.9 \mathrm{mM}$ ALA (Table 3). Under conditions of cold stress $0.6 \mathrm{mM}$ ALA indicated a drastic reduction in electrolyte leakage (Table 3 ). For comparison purpose, foliar application of ALA was more effective for maintenance of membrane integrity than seed priming. It worth mentioning that there was no significant difference between $0.6 \mathrm{mM}$ ALA with all other concentrations and methods of application at $25^{\circ} \mathrm{C}$, indicating this treatment overcome the adverse effect caused by cold. Increment in electrolyte leakage is a good reflection of oxidative damage to membrane lipids and other vital molecules such as proteins, DNA and RNA.

In the current study, cold stress increased electrolyte leakage compared to controls, in agreement with results of other studies (Schwanz and Polle, 2001). Cold stress causes overproduction of ROS, which ultimately imposes a secondary oxidative stress in plant cells (Foyer et al., 1997). Peroxidation of membrane lipids due to ROS may result in enhanced membrane fluidity, which may lead to enhanced electrolyte leakage and support the hypothesis that cold stress can induce membrane lipid peroxidation. Reduced membrane integrity resulting in electrolyte leakage has been reported with freezing in wheat (Pukacki et al., 1991). Foliar application of ALA particularly $0.6 \mathrm{mM}$ extremely prevented the enhancement of electrolyte leakage. Thus, it is assumed that plants treated with ALA might be more efficient in scavenging of ROS. The probable reason behind the decreased electrolyte leakage is the application of ALA, as it is an essential precursor in the biosynthesis of haeme, so its exogenous application boasts up the activity of haeme-based biomolecules (APX, POD and CAT) and helped to scavenge the ROS to protect against the potentially harmful effects caused by reactive oxygen under cold stress condition (Liu et al., 2011).

Effect of cold stress and 5-Aminolevulinic acid on chlorophyll

Chlorophyll content was affected by individual effect of different temperature regimes and ALA concentrations (Table 1). Generally chlorophyll content significantly decreased by cold stress treatment and increased by ALA application (Table 3). The highest chlorophyll content was observed when soybean seeds were primed in $0.3 \mathrm{mM}$ ALA solution and grown either under cold stress conditions or no stress conditions. It means that seed priming with low concentration of ALA overcomes cold stress in soybean. However, chlorophyll content decreased due to further increase in ALA concentration (Table 3). These ups and downs can be explained on one hand from the fact that ALA at low concentrations, acts as a regulator of chlorophyll and heme biosynthesis and, while on the other hand, oxidative stress might have occurred as a result of ROS generated by higher ALA concentrations. Furthermore, it is clearly known that ALA is an essential precursor in the biosynthesis of porphyrins such as chlorophyll and heme (Zhang et al., 2006). So it is easy to understand why exogenous supply of ALA would result in increased chlorophyll content. Low temperature is one factor that may limit photosynthetic activity via chlorophyll degradation. Musser et al. (1984) reported that low temperatures appear to damage the structure of chloroplasts and reduce the content of chlorophyll pigments. Previous studies have shown that chlorophyll can be bleached under cold stress due to generated ROS and oxidative stress (Noriega et al., 2007). 
492

Effect of cold stress and 5-Aminolevulinic acid on photosynthesis and stomatal conductivity

Photosynthesis rate was affected by different temperature regimes and ALA concentrations (Table 1). Typically, photosynthesis rate decreased due to cold stress (Fig. 4) and increased on account of ALA application (Fig. 5). Photosynthesis rate was significantly reduced with increasing ALA concentration (Fig. 5). Similarly, stomatal conductivity was reduced because of cold stress and improved by $0.3 \mathrm{mM}$ ALA under cold stress conditions and 0.3 or $0.6 \mathrm{mM}$ ALA at $25{ }^{\circ} \mathrm{C}$ (Table 3). The hereby observations support this assumption and show that application of low levels of ALA increased stomatal conductivity and photosynthetic rate. Cold stress induces various biochemical and physiological responses in plants and affects almost all plant functions including photosynthesis. Decrease of photosynthesis induced by low temperatures is a well-known response of chilling-sensitive plants (Yadegari et al., 2008). The obtained data are in agreement with the findings of Hotta et al. (1997a, b) who suggested that growth and yield of several crops were improved by ALA application due to increased chlorophyll content and increased photosynthetic activity. Accumulated evidence suggested that exogenous ALA at low concentrations can promote photosynthesis in some plant species. ALA treatment could improve the biosynthesis of phycocyanin and chlorophyll in algal cells and eventually improve cell growth (Sasaki et al., 1995) and could significantly restore the photosynthetic ability under low light condition in melon (Wang et al., 2004) and watermelon (Sun et al., 2009).

Effect of cold stress and 5-Aminolevulinic acid on superoxide dismutase and catalyse activity

Cold treatment resulted in higher enzyme activities of superoxide dismutase (Table 2). ALA application did not change superoxide dismutase activity at $25^{\circ} \mathrm{C}$. Conversely, under conditions of cold stress, superoxide dismutase activity increased with increasing ALA concentration (Table 2). The highest catalase activity was observed when plants were treated with $0.6 \mathrm{mM}$ ALA at $10{ }^{\circ} \mathrm{C}$. Generally, the antioxidant enzymes enhanced their activities remarkably with ALA treatment under cold stress. The effects of antioxidant enzymes in low temperature stress have been demonstrated in many experiments (Li et al., 2000; Wu et al., 2004). Superoxide dismutase converts $\mathrm{O}_{2}{ }_{2}$ radicals into $\mathrm{H}_{2} \mathrm{O}_{2}$ and $\mathrm{O}_{2}$ and then catalase dismutases $\mathrm{H}_{2} \mathrm{O}_{2}$ into water and $\mathrm{O}_{2}$. The probable reason behind the enhanced activities of catalase activity due to ALA is that it is an essential precursor in the biosynthesis of haeme, so its exogenous application boasts up the activity of haeme-based biomolecules such as superoxide dismutase and catalase (Liu et al., 2011). In addition, ALA undergoes enolization and further metalcatalyzed aerobic oxidation at physiological $\mathrm{pH}$ to yield superoxide radical, hydrogen peroxide and hydroxyl radical. Therefore, accumulation of ALA enhances reactive oxygen species levels leading to oxidative stress (Balestrasse et al., 2010).

\section{Effect of cold stress and 5-Aminolevulinic acid on proline accumulation}

Proline, soluble sugars and free amino acids have been mentioned as important compatible solutes in osmoregulation and protect plants from stress through different mechanisms, including cellular osmotic adjustment, detoxification of reactive oxygen species, protection of membrane integrity and stabilization of proteins/enzymes (Sairan and Tyagi, 2004; Ashraf and Foolad, 2007). An elevation of proline accumulation in the cold stressed plants was also observed in present study. Moreover, proline accumulation increased with increasing ALA concentration under both temperature conditions (Table 3). However, the highest accumulation was observed under cold stress conditions. It is notable that when seeds were primed with ALA, proline accumulation was higher. It is generally known that plants subjected to stress synthesize organic solutes such as glycine betaine, proline and sugar alcohols for turgor maintenance (McCue and Hanson, 1990). Contradictory results have been previously reported about whether proline plays protective role in stressed plants or just a symptom of injury under stress conditions (Misra and Gupta, 2005; Tatar et al., 2010). Also, it has been reported that ALA increases fructan (polyfructosylsucroses) content as nonstructural carbohydrate in spinach (Yoshida et al., 1995). The main question is how ALA leads to increased proline? The answer to this is not known yet; nonetheless it seems that ALA might be involved in proline synthesis and accumulation.

\section{Conclusions}

The present study provides evidence for the protective role of ALA against cold stress in young soybean plants. ALA application was effective in improving soybean growth such that $0.3 \mathrm{mM}$ concentration was relatively more effective than the other concentrations used in the current study. Moreover, foliar-applied of ALA was more helpful than seed priming method. It has been also present data showing that ALA activated the enzymatic defence system and enhanced chlorophyll content, stomatal conductivity and photosynthesis. In addition, results suggest that application of ALA decreases electrolyte leakage and increases proline accumulation. Overall, ALA application can be recommend mitigating serious problems occurring under cold stress, to prevent crop losses in soybean due to low temperatures.

\section{References}

Arnon DI (1949). Copper enzymes in isolated chloroplasts, polyphennoloxidase in Beta vulgaris. Plant Physiology 24(1):1-15.

Aroca R, Tognoni F, Irigoyen JJ, Diaz MS, Pardossi A (2001). Different root low temperature response of two maize genotypes differing in chilling sensitivity. Plant Physiology and Biochemistry 39(12):1067-1073.

Ashraf M, Foolad MR (2007). Roles of glycine betaine and proline in improving plant abiotic stress resistance. Environmental and Experimental Botany 59(2):206-216.

Balestrasse KB, Tomaro ML, Batlle A, Noriega GO (2010). The role of 5-aminolevulinic acid in the response to cold stress in soybean plants. Photochemistry 71(17-18):2038-2045.

Bates LS, Waldern RP, Teave ID (1973). Rapid determination of free proline for water stress studies. Plant and Soil 39(1):205-207.

Beale SI (1990). Biosynthesis of the tetrapyrrole pigment precursor, 5aminolevulinic acid, from glutamate. Plant Physiology 93(4):1273-1279. 
Beck EH, Fettig S, Knake C, Hartig K, Bhattarai T (2007). Specific and unspecific responses of plants to cold and drought stress. Journal of Biosciences 32(3):501-510.

Beck EH, Heim R, Hansen J (2004). Plant resistance to cold stress: Mechanisms and environmental signals triggering frost hardening and dehardening. Journal of Biosciences. 29(4):449-459.

Bindu Roy C, Vivekanandan M (1998). Role of aminolevulinic acid in improving biomass production in Vigna catjung, V. mungo, and V. radiate. Biologia Plantarum 41(2):211-215.

Broughton WJ, Dilworth M (1971). Control of leg-haemoglobin synthesis in snake beans. Biochemistry Journal 125(4):1075-1080.

Cakmak I, Horst W (2006). Effect of aluminium on lipid peroxidation, superoxide dismutase, catalase and peroxidase activities in root tip of soybean (Glycine max). Physiologia Plantarum 83(3):463-468.

Castelfranco PA, Rich PM, Beale SI (1974). The abolition of the lag phase in greening cucumber cotyledons by exogenous 5aminolevulinic acid. Plant Physiology 53:615-618.

Dionisio-Sese ML, Tobita S (1998). Antioxidant response of rice seedlings to salinity stress. Plant Science 135(1):1-9.

Ercoli L, Mariotti M, Masoni A, Arduini I (2004). Growth responses of sorghum plants to chilling temperature and duration of exposure. European Journal of Agronomy 21(1):93-103.

Foyer CH, Lopez-Delgando H, Dat JE, Scott IM (1997). Hydrogen peroxide- and glutathione-associated mechanisms of acclimatory stress tolerance and signaling. Plant Physiology 100(2):241-254.

Giannopolitis C, Ries S (1977). Superoxide dismutase occurrence in higher plant. Plant Physiology 59(2):309-314.

Gray WM, Ostin A, Sandberg G, Romano CP, Estelle M (1998). High temperature promotes auxin-mediated hypocotyl elongation in Arabidopsis. Proceedings of the National Academy of Sciences USA 95(12):7197-7202.

Hodgins RR, Öquist G (1989). Porphyrin metabolism in chillstressed seedlings of scots pine (Pinus sylvestris). Physiologia Plantarum 77(4):620-624.

Hotta Y, Tanaka T, Bingshan L, Takeuchi Y, Konnai M (1998). Improvement of cold resistance in rice seedlings by 5aminolevulinic acid. Pesticide Science 23(1):29-33.

Hotta Y, Tanaka T, Takaoka H, Takeuchi Y, Konnai M (1997a). New physiological effects of 5-aminolevulinic acid in plants: the increase of phtosynthesis, chlorophyll content, and plant growth. Bioscience Biotechnology Biochemistry 61(12):2025-2028.

Hotta Y, Tanaka T, Takaoka H, Takeuchi Y, Konnai M (1997b). Promotive effects of 5-aminolevulinic acid on the yield of several crops. Plant Growth Regulation 22(2):109-114.

Hume DJ, Jackson AKH (1981). Frost tolerance in soybeans. Crop Science 21(5):689-692.

Janská A, Maršík P, Zelenková S, Ovesna J (2010). Cold stress and acclimation what is important for metabolic adjustment? Plant Biology 12(3):395-405.

Larcher W (2001). Ökophysiologie der Pflanzen (Stuttgart: Eugen Ulmer) p 302.

Lee TM, Lur HS (1997). Role of abscisic acid in cold tolerance of rice (Oryza sativa L.) seedlings. II. Modulation of free polyamine levels. Plant Science 126(1):1-10.
Li J, Yan XF, Zu YG (2000). Generation of activated oxygen and change of cell defense enzyme activity in leaves of Korean pine seedling under low temperature. Acta Botanica Sinica 42(2):148152 (in Chinese).

Li W, Wang R, Li M, Li L, Wang C, Welti R, Wang X (2008). Differential degradation of extraplastidic and plastidic lipids during freezing and post-freezing recovery in Arabidopsis thaliana. Journal of Biological Chemistry 283(1):461-468.

Liu D, Pei ZF, Naeem MS, Ming DF, Liu HB, Khan F, Zhou WJ (2011). 5-Aminolevulinic acid activates antioxidative defence system and seedling growth in Brassica napus L. under water-deficit stress. Journal of Agronomy and Crop Science 197(4):284-295.

McCue KF, Hanson AD (1990). Drought and salt tolerance: Towards understanding and application. Trends in Biotechnology 8:358-362.

Memon SA, Hou X, Wang LJ, Li Y (2009). Promotive effect of 5aminolevulinic acid on chlorophyll, antioxidative enzymes and photosynthesis of Pakchoi. Acta Physiologiae Plantarum 31(1):51-57.

Misra N, Gupta AK (2005). Effect of salt stress metabolism in two high yielding genotypes of green gram. Plant Science 169(2):331-339.

Musser RL, Thomas SA, Kramer PJ (1983). Short and long term effects of root and shoot cold of Ransom soybean. Plant Physiology 73(3):778-783.

Musser RL, Thomas SA, Wise RR, Peeler TC (1984). Chloroplast ultrastructure, chlorophyll fluorescence, and pigment composition in cold-stressed soybeans. Plant Physiol. 74(4):749754.

Nadella V, Shipp MJ, Muday GK, Wyatt SE (2006). Evidence for altered polar and lateral auxin transport in the gravity persistent signal (gps) mutants of Arabidopsis. Plant Cell and Environment 29(4):682-690.

Naeem MS, Jin ZL, Wan GL, Liu D, Liu HB, Yoneyama K, Zhou WJ (2010). 5-Aminolevulinic acid improves photosynthetic gas exchange capacity and ion uptake under salinity stress in oilseed rape (Brassica napus L.). Plant and Soil 332(1):405-415.

Nayyar H, Bains TS, Kumar S (2005). Chilling stressed chickpea seedlings: effect of cold acclimation, calcium and abscisic acid on cryoprotective solutes and oxidative damage. Environmental and Experimental Botany 54(3):275-285.

Nishihara E, Kondo K, Masud Parvez M, Takahashi K, Watanabe K, Tanaka K (2003). Role of 5-aminolevulinic acid (ALA) on active oxygen-scavenging system in $\mathrm{NaCl}$ treated spinach (Spinacia oleracea). Plant Physiology 160(9):1085-1091.

Noriega GO, Yannarelli GG, Balestrasse KB, Batlle A, Tomaro ML (2007). The effect of nitric oxide in heme oxygenase gene expression in soybean leaves. Planta 226(5):1155-1163.

Pukacki PM, Kendall EJ, McKersie BD (1991). Membrane injury during freezing stress to winter wheat (Triticum aestivum L) crowns. Journal of Plant Physiology $138(5): 516-521$. 
494

Rodríguez P, Torrecillas A, Morales MA, Ortuño MF, Sánchez-Blanco MJ (2005). Effects of $\mathrm{NaCl}$ salinity and water stress on growth and leaf water relations of Asteriscus maritimus plants. Environmental and Experimental Botany 53(2): 113-123.

Sairan RK, Tyagi A (2004). Physiology and molecular biology of salinity stress tolerance in plants. Current Science 86(3):407-421.

Sakai A, Larcher W (1987). Frost survival of plants: response and adaptation to freezing stress Ecol. Studies 62. Billings WD, Golley F, Lange OL, Olson JS, Remmert H (Eds) Berlin, New York: Springer.

Sasaki K, Marquez FJ, Nishio N, Nagai S (1995). Promotive effects of 5-aminolevulinic acid on the growth and photosynthesis of Spirulina platensis. Journal of Fermentation and Bioengineering 79(5):453-457.

Schwanz P, Polle A (2001). Differential stress responses of antioxidative systems to drought in pendunculate oak (Quercus robur) and maritime pine (Pinus pinaster) grown under high $\mathrm{CO}_{2}$ concentrations. Journal of Experimental Botany 52(354):133-143.

Shibasaki K, Uemura M, Tsurumi S, Rahman A (2009). Auxin response in Arabidopsis under cold stress: underlying molecular mechanisms. The Plant and Cell 21(12):38233838 .

Stobart AK, Ameen-Bukhari J (1984). Regulation of alphaaminolevulinic acid synthesis and protochlorophyllide regeneration in the leaves of dark-grown barley (Hordeum vulgare) seedlings. Biochemistry Journal 222(2):419-426.

Sun YP, Zhang ZP, Wang LJ (2009). Promotion of 5aminolevulinic acid treatment on leaf photosynthesis is related with increase of antioxidant enzyme activity in watermelon seedlings grown under shade condition. Photosynthetica 47(3):347-354.

Tatar O, Brueck H, Gevrek MN, Asch F (2010). Physiological responses of two Turkish rice (Oryza sativa L.) varieties to salinity. Turkish Journal of Agriculture and Forestry 34(6):451-459.

Tewari AK, Tripathy BC (1998). Temperature-stress-induced impairment of chlorophyll biosynthetic reactions in cucumber and wheat. Plant Physiology 117(3):851-858.

Van Heerden PDR, Krüge GHJ, Loveland JE, Parry MAJ, Foyer CH (2003). Dark chilling imposes metabolic restrictions on photosynthesis in soybean. Plant, Cell and Environment 26(2):323-337.

Wang LJ, Jiang WB, Huang BJ (2004). Promotion of 5aminolevulinic acid on photosynthesis of melon (Cucumis melo) seedlings under low light and chilling stress conditions. Physiologia Plantarum 121(2):258-264.

Watanabe K, Nishihara E, Watanabe S, Tanaka T, Takahashi K, Takeuchi Y (2006). Enhancement of growth and fruit maturity in 2-year-old grapevines cv. Delaware by 5aminolevulinic acid. Plant Growth Regulation 49(1):3542.
Watanabe K, Tanaka T, Hotta Y, Kuramochi H, Takeuchi Y (2000). Improving salt tolerance of cotton seedlings with 5-aminolevulinic acid. Plant Growth Regulation 32(1):99103.

Weinstein JD, Beale SI (1985). Enzymatic conversion of glutamate to 5-aminolevulinic acid in soluble extracts of the unicellular green alga, Chlorella vulgaris. Archives Biochemistry Biophysics 237(2):454-464.

Wilkinson S, Clephan AL, Davies WJ (2001). Rapid low temperature-induced stomatal closure occurs in coldtolerant Commelina communis leaves but not in coldsensitive tobacco leaves, via a mechanism that involves apoplastic calcium but not abscisic acid. Plant Physiology 126(4):1566-1578.

Wu JH, Yang L, Sun GR (2004). Generation of activated oxygen and change of cell defense enzyme activity in leaves of maize seeding under the stress of low temperature. Bulletin of Botanical Research 24(4):456-459 (in Chinese).

Wyatt SE, Rashotte AM, Shipp MJ, Robertson D, Muday GK (2002). Mutations in the gravity persistence signal loci in Arabidopsis disrupt the perception and/or signal transduction of gravitropic stimuli. Plant Physiology 130(3):1426-1435.

Xia JH, Zhao H, Liu WZ, Li LG, He YK (2009). Role of cytokinin and salicylic acid in plant growth at low temperatures. Plant Growth Regulation 57(3):211-221.

Xing W, Rajashekar CB (2001). Glycine betaine involvement in freezing tolerance and water stress in Arabidopsis thaliana. Environmental and Experimental Botany 46(1):21-28.

Yadegari LZ, Heidari R, Carapetian J (2008). The influence of cold acclimation on proline, malondialdehyde (MDA), total protein and pigments contents in soybean (Glycine max) seedlings. Journal of Biological Sciences 3(1):74-79.

Yoshida R, Tanaka T, Hotta Y (1995). Pysiological effects of 5 -aminolevulinic acid in vegetable crops. Abs of $15^{\text {th }}$ International Conference on Plant Growth Substances, Minneapolis, Minnesota USA pp 417.

Youssef T, Awad MA (2008). Mechanisms of enhancing photosynthetic gas exchange in date palm seedlings (Phoenix dactylifera L.) under salinity stress by a 5aminolevulinic acid-based fertilizer. Journal of Plant Growth Regulation 27(1):1-9.

Zhang ZJ, Li HZ, Zhou WJ, Takeuchi Y, Yoneyama K (2006). Effect of 5-aminolevulinic acid on development and salt tolerance of potato (Solanum tuberosum L.) microtubers in vitro. Plant Growth Regulation 49(1):27-34. 